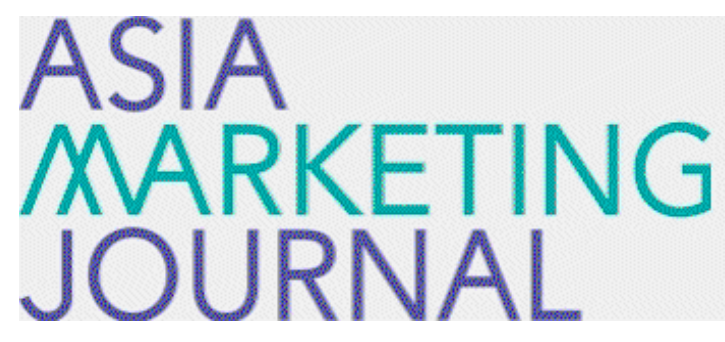

ASIA MARKETING JOURNAL

Volume 19 | Issue 1

Article 2

4-30-2017

\title{
How Network Structure Impacts Firm Performance
}

Kyunghee Kim

Jeongtae Kim

Junhong Min

Ryu

Follow this and additional works at: https://amj.kma.re.kr/journal

Part of the Marketing Commons

\section{Recommended Citation}

Kim, Kyunghee; Kim, Jeongtae; Min, Junhong; and Ryu (2017) "How Network Structure Impacts Firm Performance," Asia Marketing Journal: Vol. 19 : Iss. 1 , Article 2.

Available at: https://doi.org/10.15830/amj.2017.19.1.19

This Article is brought to you for free and open access by Asia Marketing Journal. It has been accepted for inclusion in Asia Marketing Journal by an authorized editor of Asia Marketing Journal. 


\title{
How Network Structure Impacts Firm Performance: The Moderating Effect of Network Openness and Interfirm Governance
}

\author{
Kyunghee Kim* \\ Jeongtae Kim** \\ Junhong Min*** \\ Sungmin $\mathrm{Ryu}^{* * * *}$
}

Despite the importance of the impact of network structure on the relationships between firms and firm performance, few studies have investigated these effects. This study investigates how network openness influences the relationships between TSI, opportunism, technological uncertainty, and supplier performance. We also try to figure out how network openness functions as a governance mechanism.

Key words: Network openness, Governance, TSI, Opportunism, Technological uncertainty

\section{Introduction}

Understanding how dyadic exchange is influenced by the broader channel environment has become a central issue in the B2B marketing field. Recent network research studies revealed that focal dyadic relationships are influenced by other relationships that represent "vertically-connected dyads." For example, McFarland, Bloodgood, \&
Payan (2008) found that the strategy used by the manufacturer in a manufacturer-dealer relationship tends to be used by the dealer in a dealer-customer relationship. Similarly, when selecting vendors, buyers consider not only the buyer-vendor relationship but also the vendorsupplier relationship because the buyer can benefit from good vendor-supplier relationships (Wuyts et al., 2004). Furthermore, other scholars (e.g., Wang, Gu, \& Dong, 2013) have provided

\section{Adjunct Professor in School of International Affairs Yonsei University (Future0801@naver.com)}

** Doctoral Student in School of Business Sungkyunkwan University (jtkim.corepharm@gmail.com)

*** Associate Professor of Marketing School of Business \& Economics Michigan Technological University (jmin@mtu.edu)

**** Professor in School of Business Sungkyunkwan University (smryu@skku.edu), Corresponding Author 
evidence that the network provides governance implications. They have found that punishing a distributor significantly reduces observers' (i.e., other distributors) opportunistic behaviors. These research studies have contributed to the development of network research and shed light on the governance implications of relationships within a network.

With few exceptions (e.g., Anita \& Frazier, 2001), previous B2B research has not fully taken into account network characteristics and their impact on interfirm governance and firm performance despite the fact that different network characteristics impact firm behavior and firm performance differently. For example, in franchisor-franchisee relationships, the franchisor is concerned with severe contract enforcement due to a highly dense network characterized by a high level of information sharing (Anita \& Frazier 2001). The same study also revealed that when an individual franchisee has a strong position in the network (i.e., network centrality), the franchisor refrains from severe contract enforcement. Research in outside marketing further revealed that while network centrality, tie strength, and tie stability have a positive relationship with firm performance, tie quality does not (Li, Veliyath, and Tan, 2013). These studies suggest the need to examine the impact of other types of network characteristics in the B2B context.

Therefore, in this study, we investigate the effect of network openness, a network characteristic, referring to the degree to which outside network members easily enter into a certain network. As more firms open a section on their website in order to find suppliers or resellers (e.g., the HP Partner Program), they are able to secure available alternatives. At the same time, the current level of network openness is rising, and such a business environment may have a positive or negative influence on the current suppliers. Thus, it is worthwhile to investigate how this situation impacts firm behavior and firm performance.

We develop our conceptual framework on the basis of an integration of transaction cost economics (TCE) and network theory to explore the impact of network openness. In this way, our study contributes to network governance research and network characteristics research at the same time. Prior research (Eisingerich \& Bell, 2008) employing network openness focuses on firm performance on the basis of case studies. These studies do not suggest the governance function of network openness.

Therefore, we extend the empirical domain of network openness. In addition to this, we also empirically prove that network openness has governance implications.

The rest of this article is organized as follows: We first briefly provide a classification of network theories to encourage a better understanding of network structure and its impact on business interactions. We then provide the conceptual framework of network openness on which this 
study's propositions are predicted. We then propose our proposition based on network openness. Finally, we present the implications and discussion.

\section{Theoretical Background and Proposition}

Scholars (e.g., Burt et al., 1994) classify network studies into four broad groups depending on how network structure affects the behavior of network members: inequality hypotheses, contingency hypotheses, embedding hypotheses, and contagion hypotheses.

Although every event that surrounds a firm does not necessarily affect it (Pfeffer \& Salancik, 1978), in the larger social context, network structure imposes a constraint on the behaviors of network members. For example, in a study of the relationship between network centrality and firm abnormal returns, Swaminathan and Moorman (2009) demonstrated that partners of a central firm in a network are likely to grant the central firm more bargaining power because such position means that the firm can wield power and influence. Therefore, the firm in a central network position is able to design the new relationship for stronger financial performance.

The four categories are as follows. First, inequality theory accounts for the resource disparity between individuals, groups, and organizations (Burt et al., 1994). Gu, Hung, and Tse (2008) showed why a certain organization has more resources through Guanxi, which influences market performance. According to them, a firm that builds a relationship with government-related firms (e.g., state-owned enterprises and joint firms between local government and individuals) easily obtains advantages over other firms in terms of obtaining land, licenses, and distribution channels. Consequently, other firms that do not have this relationship have less opportunity to access the same capital.

Second, embedding theory explains how economic action is affected by social relations (Burt et al., 1994). Studies belonging to this category theoretically approach the business relationship on the basis of network theory, but incorporate transaction cost theory. For example, Wang, Gu, and Dong (2013) investigated the effects of punishment on observers of those who are interested in the punishment of a peer with dysfunctional behavior (i.e., ex post opportunism).

Wuyts et al. (2004) described the importance of social relations in selecting/preferring business partners. When buyers select vendors, they consider the vendor-buyer relationship but also vendorsupplier relationships as well. Similarly, in a study examining the impact of customer innovation knowledge on supplier innovation, Noordhoff et al. (2011) argued that a high level of embeddedness between a supplier and customer increases the risk of opportunism.

Third, contagion theory describes how ideas and behaviors are transmitted between two 
individuals and, finally, assimilated (Burt et al., 1994). McFarland, Bloodgood, and Payan (2008) empirically proved the existence of supply chain contagion - the spread of interfirm behaviors from one dyad to an adjacent dyad in the supply chain. In their study, an influence strategy used by a manufacturer in the manufacturer-dealer relationship is more likely to be used by the dealer in the dealer-customer relationship. Thus, like people, firms are influenced by the presence of habits that exist within the larger social context.

Fourth, contingency theory explains that a process changes as a function of its location in the network structure (Burt et al., 1994). Anita and Frazier (2001) described how the position of an agent influences a principle's response to contract enforcement. If the agent occupies a position of prominence for the agent's network, meaning the network centrality of the agent, it could influence information flow and behavioral expectations among other agents. Therefore, the principle intention to severely enforce the contract to the central agent decreases to some degree.

\subsection{Network Openness}

Network openness refers to the degree to which buyers are willing to open their pool of exchange partners beyond their existing partners and consider all firms outside of the network as potential suppliers (Eisingerich, Bell, \& Tracy, 2010). The boundary of a business network in our study is confined to the supply chain network and therefore the vertical network relationship and network membership diversity is also confined to current and potential suppliers.

The primary benefit of network openness is providing new network members with new knowledge and new ways of operating (Eisingerich et al., 2010). Some studies demonstrate the advantages of an open network. For example, Rodan and Galunic (2001) showed positive relationships between knowledge heterogeneity and levels of innovation. McEvily \& Zahher (1999) also proved that access to diverse information leads to competitive capabilities in a diverse network. In the interfirm marketing field, Swaminathan and Moorman (2009) explained network efficiency as the level of knowledge, skill, and capability heterogeneity of network members and show an inverted U-shaped relationship between network efficiency and firm abnormal returns. Therefore, a diversified network has a positive relationship with firm returns to some extent. Eisingerich and Bell (2008) also showed a positive relationship between a diversified network and firm performance. Although network openness has some advantages, mentioned above, we argue that an open network is likely to affect firm decision making and behavior. For example, under a high level of open network structure, sellers may try to modify their marketing mix decisions (Wathne, Biong \& Heide, 2001) to create enhanced customer value. In addition, such network structure may induce certain firm behaviors (i.e., curbing 
opportunistic behavior) that promote the continuance of a relationship with buyers (Jap \& Ganesan, 2000). It is, therefore, interesting to look at how network openness impacts firm behavior and performance.

From the buyer's point of view, a high level of network openness is quite beneficial because it helps to find more effective suppliers. For example, a new supplier offering a lower price enables the buyer to realize both immediate cost savings and considerable savings over time (Kranton, 1996; Wathne, Biong, \& Heide, 2001). A new potential supplier can also provide both competitiveness and a broader range of products for the buyer (Wathne, Biong, \& Heide, 2001). Having multiple product options may allow the buyer to save on transaction costs, such as searching costs. Also, a new supplier may offer "one-stop shopping" for the buyer, which means that all required products and services are available from the same supplier (Wathne, Biong, \& Heide, 2001).

The effects of network openness are partly related to resource dependence logic in that opening the network to potential suppliers will most likely result in increased alternatives for buyers. The main premise of resource dependence theory implies that an increased number of supply sources results in reduced power, and therefore influence, of the parties that supply resources (Pfeffer \& Salancik, 1978).

To suppliers, a buyer's decisions to increase the level of network openness may give a signal that the suppliers are entering into a more competitive market. An increased level of network openness could be a source of fear and anxiety to existing suppliers. Once the suppliers perceive a new environment, they need to define and interpret the new context and change their behaviors to correspond to the situation (Pfeffer $\&$ Salancik, 1978). The suppliers are likely to hesitate to behave opportunistically and try to maintain a conflict-free relationship with buyers. In this process, the suppliers are most likely to conform to the expectations of buyers by regulating and modifying their behaviors. In this regard, buyer willingness to accept new suppliers could work as an efficient governance strategy.

\subsection{TSI}

Transaction-specific investment (TSI) refers to an investment made by a supplier, having the value only within an exchange relationship between the supplier and buyer. This includes money invested in a joint R\&D program, the building of new plants, and equipment for production. For example, Samsung Engineering, a Korean construction company, requires its design suppliers to build Engineering Work Place (EWP) systems, which cannot be used in exchange relations other than Samsung. Due to such attributes, this type of investment represents the transferability of assets (Williamson, 1985) and creates dependency of the firms that invest in these assets. 
Previous studies have proven that unilateral TSI increases commitment in the relationship (Anderson \& Weitz, 1992), control over partner decisions (Heide \& John, 1992), joint action, relationship length (Joshi \& Stump, 1999b; Yu, Liao, \& Lin, 2006), and information sharing (Frazier et al., 2009) and that it decreases opportunism (Jap \& Anderson, 2003; Vázquez, Iglesias, \& Rodríguez-del-Bosque, 2007).

In spite of the advantages, some mixed results have been shown in the relationship between TSI and performance. Some studies (e.g., Heide and Stump, 1995: Artz, 1999) found a negative relationship between TSI and performance while some others (e.g., Lohtia and Krapfel, 1994; Brown, Dev, \& Lee, 2009) argued for the positive impact of TSIs on performance. The mixed results indicate that depending on the context, there might be different results.

Ganesan (1994) and Joshi and Stump (1999a) indicated that TSIs made by a firm increase the firm's dependence on its exchange partners. Consider a supplier that made TSIs for a certain exchange with a buyer. The supplier invests money and effort into machinery, instruments, and procedures according to the requirements of the buyer, which pose a "contractual hazard" (Williamson, 1985: Heide \& John, 1992) to the supplier. In this case, the supplier would desire to maintain the overall health of the relationship (Artz, 1999). Otherwise, its sunk costs would be gone without any benefit to the supplier. Such circumstances influence the supplier to put in a large amount of effort to increase the satisfaction of the buyer, which is most often achieved through improved performance.

\section{P1: TSI made by a supplier increases the performance of the supplier.}

Once a TSI is made by a supplier, it creates a disparity between the supplier and the buyer. Whereas the buyer would have to pay the "at-least cost" to persuade alternative suppliers to make an investment, the supplier would be left with a substantial loss if the relationship were terminated (Williamson, 1996).

As the level of network openness increases, some aggressive suppliers that might be willing to make TSIs may appear. Intuitively, when there are many similar players in a market, competition for winning transactions will be strong. At one extreme, the buyer does not need to pay anything to search and induce new investment. In addition, new potential suppliers that provide differentiated products may also make the buyer more likely to consider switching suppliers (Wathne, Biong, \& Heide, 2001). The supplier that made the TSI becomes more vulnerable in such an environment because the possibility of relationship termination is likely to go up. This would probably happen even when the buyer and the supplier have a close relationship because intimacy is less important than economic benefits (Wathne, Biong, \& Heide, 2001). Consequently, the supplier most likely adapts its 
activities in order to survive (Pfeffer \& Salancik, 1978: 3) and to avoid a substantial loss resulting in relationship termination. To achieve this goal, the supplier needs to satisfy its buyer through performance improvements.

Therefore, we argue that the positive relationship between TSI and firm performance gets stronger as the level of network openness increases because the firm that made the investment will put additional effort into its performance in order to prevent its investment from being useless.

P2: The greater the level of network openness, the stronger the positive relationship between the supplier's TSI and supplier performance.

\subsection{Opportunism}

Opportunism is destructive to both relationships and performance and is defined as "self-interest seeking with guile" (Williamson, 1985). It involves "false or empty, that is, self-disbelieved, threats and promises" (Goffman, 1969; Williamson, 1975). In our study, we define opportunism as any behavior and intention to benefit at the expense of others, such as altering or hiding facts and making false promises to exchange partners.

The negative relationship between opportunism and performance has been supported by scholars (e.g., Gundlach, Achrol, \& Mentzer 1995;
Wathne \& Heide 2000; Samaha, Palmatier, \& Dant 2011). The party that is the victim of the other party's opportunistic behavior suffers from increased costs (Wathne \& Heide, 2000). The victimized party has to face damage while the opportunistic party can also ruin itself in terms of its performance.

A supplier can probably obtain immediate benefits from withholding or distorting information. However, such behaviors will encourage its buyer to make wrong managerial decisions that can substantially damage the buyer. In such situations, the easiest way to prevent opportunistic behavior is to squeeze the supplier. Furthermore, as the buyer realizes that the supplier cheated and that it incurred damage, the buyer may become more demanding of excessive or unnecessary documentation and procedures to prevent the same thing happening again.

Seeking a chance to deceive the buyer shows that the supplier lacks the intention to improve its performance. Such suppliers may focus on the delivery or selling of products, but may not care about product quality. Even when it notices a deficit in the product, it may just hide it and deliver the product in expectation of it not being detected. Therefore, there is very little likelihood of improving performance, and the actual performance will deteriorate.

P3: A supplier's opportunism will have negative effects on the supplier's firm performance. 
An increased number of potential suppliers will be perceived as competitive to the incumbent suppliers. Opportunistic behavior is less likely to occur in such situations. Since a supplier normally and inherently has a stronger motivation to maintain a business relationship than a buyer does, firms are more likely to improve their activities and behaviors (Pfeffer \& Salancik, 1978). When a supplier perceives many similar companies in the market, it is less likely to behave opportunistically toward the buyer (Pfeffer \& Salancik, 1978). The supplier is well aware that the buyer may switch to a new supplier if it detects opportunistic behavior in the supplier. Therefore, the perceived threat of a terminated relationship would make the seller reduce its opportunistic behavior and put forth effort to improve performance.

A network consists of many actors, and each individual dyadic relationship influences other relationships in the network (Håkansson \& Johanson, 1993). If a supplier behaves opportunistically to pursue its own interests, it will eventually earn a negative reputation in the network. This will have a negative impact on other exchange relationships it has with other partners. In contrast, if the supplier is honest in its current relationship, it will be able to establish a positive reputation and consequently have a positive impact on other relationships because exchange in one relationship is conditioned by exchange in another (Håkansson \& Johanson, 1993). Thus, network openness functions as a governance mechanism by reducing opportunism. Therefore, we argue that network openness could moderate a negative relationship between opportunism and performance.

P4: The greater the level of network openness, the weaker the negative relationship between supplier opportunism and supplier performance.

\subsection{Technological Uncertainty}

As a key independent construct, environmental uncertainty has been actively researched. Environmental uncertainty is defined as unanticipated changes in circumstances surrounding an exchange (Rindfleisch \& Heide, 1997).

Researchers provide various dimensions of uncertainty such as 'technological unpredictability,' which refers to the inability to forecast technical requirements in the relationship accurately (Walker and Weber, 1984; Heide and John, 1990). In our study context, technological uncertainty can be associated with engineering-related software and materials that are used for building a plant. For example, a supplier may experience uncertainty following changes in the standards or specifications (Heide and John, 1990) of steel materials, as energy drilling is expanding to extreme areas such as the deep sea.

Previous studies have found a negative relationship between technological uncertainty and relationship continuity or long-term orientation because buyers 
want to switch to a new partner with the appropriate technological capabilities to maintain flexibility and respond to uncertainty (Heide and John, 1990; Joshi and Stump, 1999b).

No studies in the existing literature have examined the relationship between technological uncertainty and performance. If the technology used in a main product is standardized, it increases the adaptability of firms (Josh and Stump, 1999b). However, when there is no standardized technology, technological uncertainty increases (Josh and Stump, 1999b). In such situation, continuous efforts on the part of firms are required in order to not fall behind in the competition. However, when technology changes quickly, it naturally leads to reduced performance due to inappropriate technology being employed. It is difficult to develop or improve technology on the basis of the perfect prediction of the future because no firm in the world can predict exactly what kind of technology will be required in the future. Therefore, existing technology becomes inappropriate technology when technology employed in an industry changes quickly. Consequently, firm performance will be reduced.

P5: Technological uncertainty will have negative effects on supplier performance

Because technological uncertainty decreases the adaptability of firms for markets, such uncertainty will encourage a buyer to develop relationships with multiple channel partners
(Ganesan, 1994). Therefore, the buyer will attempt to increase the level of network openness to find alternative suppliers. As the level of network openness increases, a severe and competitive environment for the existing suppliers will be created.

From the supplier's perspective, the expected intense competition will be perceived as pressure to improve performance. The supplier is well aware that the buyer has to rely on other firms that have technology the buyer needs to find other firms that have technology the buyer needs (Pfeffer \& Salancik, 1978). The more open the network is, the higher the chance of finding a new partner the buyer has. Being under such pressure, the supplier is more likely to put its best foot forward to improve performance to satisfy its buyer and to maintain the exchange relationship. The supplier is likely to provide a newly developed product specification that can increase efficiency before the buyer asks it to do so. Thus, we argue that the negative relationship between technological uncertainty and supplier performance will be positive when network openness is high.

P6: When the level of network openness is greater, the negative relationship between technological uncertainty and supplier performance will be reduced. 


\section{Discussion}

The emphasis placed on the need to go beyond the traditional focus of the individual dyadic relationship has led to further research on inter-dyadic relationships (e.g., Wathne, Biong, \& Heide, 2001; Antia \& Frazier, 2001). Despite the growing body of research concerning the network environment, empirical studies on network governance and the impact of the network structure on business relationships remain rare. Recognizing these gaps, we made an attempt to investigate the effectiveness of network openness on dyadic relationships.

The current study makes several contributions to this field of research. First, our study focuses on the impact of network structure, while extant network studies in this field focused on the interaction of business relationships to achieve collective/individual interest (Salancik, 1995; Wuyts and Van den Bulte, 2012) through network embeddedness. By focusing on a particular network structure, this study enables us to understand how the macro-level environment affects firms' individual actions. Firms, especially suppliers in our study, demonstrated increased performance when they made TSIs as network openness increased. A high level of network openness was also found to curb supplier opportunism. The suppliers, however, showed decreased performance as they confronted an uncertain environment and a high level of network openness at the same time.

Second, this study found the possibility that a certain network structure functions as a governance mechanism. This is probably not intended or expected by buyers who announce that they will recruit qualified suppliers by opening the supplier pool beyond the current business relationships. In such an unstable situation, a supplier's motivation to maintain healthy business conditions would be stronger if they made TSIs. The best way to maintain business is to satisfy the buyers through high quality products and punctual delivery. In a similar vein, this study shows the possibility of using network structure as a means of curbing opportunism. Like other positive mechanisms, such as monitoring, incentives, and socialization to safeguard against opportunism (Wang et al., 2013), network openness could be a governance mechanism. Such positive means could be more effective than negative means such as sanction (Wang, Gu, \& Dong, 2013) because they do not necessarily cause conflict between suppliers and between suppliers and buyers as well.

One thing that should be noted is that network openness does not always positively influence the conduct of suppliers. As the study results show, network openness worsened the negative relationship between technological uncertainty and performance.

In an individual setting, people sometimes “choke under pressure," defined as performing suboptimally under high pressure conditions, and 
their performance becomes unsatisfactory; this behavior is more likely when the task is complex, which results in an undermining of performance attainment (Baumeister \& Showers, 1986; Murayama \& Elliot, 2012).

Applying the study results to the company level, firms may feel greater difficulty when they face a high level of network openness and technological uncertainty in combination. In a way, this result is similar to a previous study (Samaha, Palmatier, \& Dant, 2011) that shows dual expropriation through both unfairness and opportunism, which causes strong emotional backlash in the victim. In our study, the combination of an increased number of competitors and an uncertain environment in exert pressure on companies, and under this pressure the companies might give up on improving performance and perform in an unsatisfactory manner.

\section{Managerial Implications}

Managers often deploy certain decisions to obtain intended results. If mangers fully grasped the ramifications of the decisions that they made, those decisions could be better utilized. Firms are able to prepare solutions to mitigate the expected problems or reconsider executing the initial marketing decisions if undesirable consequences are predicted. Without accurate predictions, firms may use resources in an ineffective way and may have difficulties.

This research shows that managers should be aware of the exact effects of decisions they make. Network openness benefits firms that require new information and technology. Our research, however, suggests that network openness influences firm performance not by providing new knowledge, but by combining with the situations the firms face.

Network openness was found to have a positive influence when suppliers had TSIs. In addition, it was also proven to curb the opportunism of suppliers. Therefore, network openness can be considered a network structure that helps buyers govern channel members to some extent. However, it should also be noted that network openness will not always have a positive impact on firm performance. If transaction partners are faced with technological uncertainty, a high level of network openness might not be a good decision. In an environment of technological uncertainty, network openness increases the pressure on suppliers, and hence performance is likely to be decreased. It may be helpful to maintain a moderate level of network openness in this situation, if possible.

\section{Limitations and Further Research}

Despite its contributions, this research study 
has some limitations. First, the construct of network openness was only viewed from the buyer's perspective. That is, this research measured and focused on how actively buyers seek second-tier suppliers. As a network member, a supplier could also actively find new customers and attempt to switch exchange partners, though this is somewhat rare in reality. Therefore, further research needs to include the supplier's perspective to address all of the effects of network openness.

Second, questionnaires were distributed only to the prime suppliers of the top manufacturers. TSI, opportunism, and firm performance of second-tier suppliers were measured as perceptions of the prime suppliers. Therefore, the evaluation of the level of performance and opportunism were possibly, but not necessarily, inaccurate.

Third, technological uncertainty in engineering, especially in the plant engineering industry, has been relatively slow to change compared with other fast-changing industries, such as information technology. Also, this industry is somewhat specialized in terms of technology, and therefore, the number of suppliers is somewhat limited. Such industry-specific characteristics imply that firms in this industry may be more sensitive to changes in network structure and technology. Changes that are considered small to other companies may be perceived as huge changes to firms in the engineering industry. A question for further research is how firms that fall under the category of a fast-changing technological industries respond to network openness. They may not be pressured by network openness because companies change transaction partners frequently industrywide due to rapid technological advances. Exploring the impact of network openness on the channel relationship in other industries would be a useful topic of future research.

〈Received March 28. 2017〉

〈Revised April 24. 2017〉

〈Accepted April 24. 2017〉

\section{References}

Achrol, R. and Kotler P. (1999), Marketing in the Network Economy, Journal of Marketing; Vol. 63 (Special issues), P. 146-163

Anderson, E. and Weitz B. (1992), "The Use of Pledges to Build and Sustain Commitment in Distribution Channels," Journal of Marketing Research, Vol. 29(February), pp. 18-34

Anderson, J., Håkansson H., and Johanson J. (1994), "Dyadic Business Relationships Within a Business Network Context," Journal of Marketing, Vol. 58(October), pp.1-15

Antia, K. and Frazier G. (2001), The Severity of Contract Enforcement in Interfirm Channel Relationships, Journal of Marketing, Vol. 65 (October), P. 67-81

Artz, K. (1999), "Buyer-Supplier Performance: The Role of Asset Specificity, Reciprocal Investments and Relational Exchange," British Academy of Management, Vol. 10, 
pp. $113-126$

Baumeister, R. and Showers C. (1986), “A

Review of Paradoxical Performance Effects:

Choking Under Pressure in Sports and

Mental Tests," European Journal of Social

Psychology, Vol. 16 No.4, pp. 361-383

Brown, J., Dev C., and Lee D. (2000), “Managing

Marketing Channel Opportunism: The Efficacy of Alternative Governance Mechanisms," Journal of Marketing, Vol. 64(April), pp. 51-65

Burt, R., Gabbay S., Holt G., and Moran P. (1994), "Contingent Organization as a Network Theory: The Culture-Performance Contingency Function,” Scandinavian Sociological Association, Vol. 37, pp. 345-370

Coleman, J. (1988), "Social Capital in the Creation of Human Capital," American Journal of Sociology, Vol. 94, pp. 95-120

Eisingerich, A. and Bell S. (2008), "Managing

Networks of Interorganization Linkages and Sustainable Firm Performance in Businessto-Business Service Contexts," Journal of Service Marketing, Vol. 22 No.7, pp. 494504 , and Tracy P. (2010),

"How Can Clusters Sustain Performance? The Role of Network Strength, Network Openness, and Environmental Uncertainty," Research Policy, Vol. 39, pp. 239-253

Fornell, C. and Larcker D. (1981), Evaluating Structural Equation Models with Unobservable Variables and Measurement Error (1981),
Journal of Marketing Research, Vol. 18(1), pp. $39-50$

Frazier, G., Maltz E., Antia K., and Rindfleisch A. (2009), "Distributor Sharing of Strategic Information with Suppliers," Journal of Marketing, Vol. 73(July), pp. 31-43

Ganesan, S. (1994), "Determinants of Long-Term Orientation in Buyer-Seller Relationships," Journal of Marketing, Vol. 58(April), pp. 1-19

Ghosh, M. and John G. (1999), "Governance Value Analysis and Marketing Strategy," Journal of Marketing, Vol. 63(Special Issues), pp. $131-145$

Goffman, E. (1969), Strategic Interaction, University of Pennsylvania Press, Philadelphia Gonner, R., Morgan N., and Perrreault Jr. W. (2011), Is Retail Category Management Worth the Effort (and Does a Category Captain Help or Hinder?), Journal of Marketing, Vol. 75(September), pp. 18-33 Granovetter, M. (1973), The Strength of Weak Ties, American Journal of sociology, Vol. 78(6), pp. 1360-1380

Grewal, R., Chakravarty A., and Saini A. (2010), "Governance Mechanisms in Business-toBusiness Electronic Markets," Journal of Marketing, Vol. 74 (July), pp. 45-62

Gu, F., Hung K., and Tse D. (2008), When Does Guanxi Matter? Issues of Capitalization and Its Dark Sides, Journal of Marketing, Vol. 72(July), P. 12-28 , Kim N., Tse D., and Wang D. (2010), 
Managing Distributors' Changing Motivations over the Course of a Joint Sales Program, Journal of Marketing, Vol. 74(September), pp. $32-47$

Gundlach, Gregory, Ravi Achrol, and John Mentzer (1995), "The Structure of Commitment in Exchange," Journal of Marketing, 59 (January), pp.78-92

Håkansson, H. and Johanson J. (1993), "The Network as a Governance Structure: Interfirm Cooperation beyond Markets and Hierarchies," in Grabher G. (Ed.), The Embedded Firm: On the Socioeconomics of Industrial Networks, Routledge, London, UK

Heide, J. (1994), "Interorganizational Governance in Marketing Channels," Journal of Marketing, Vol. 58(January), pp. 71-85 , and John G. (1990), "Alliances in Industrial Purchasing: The Determinants of Joint Action in Buyer-Supplier Relationships," Journal of Marketing Research, Vol. 27 (Feb), pp. 24-36 and (1992), “Do Norms Matter in Marketing Relationships"? Journal of Marketing, Vol. 56(April), pp. 32-44 and Stump R. (1995), "Performance Implications of buyer-Supplier Relationships in Industrial Markets: A Transaction Cost Explanation," Journal of Business Research, Vol. 32, pp. 57-66

Jap, S. and Anderson E. (2003), "Safeguarding Interorganizational Performance and Continuity under Ex Post Opportunism," Marketing
Science, Vol. 49 No. 12, pp. 1684-1701 and Ganesan S. (2000), "Control Mechanisms and the Relationship Life Cycle: Implications for Safeguarding Specific Investments and Developing Commitment," Journal of Marketing Research, Vol. 37, May, pp.227-245

Joshi, A. and Stump R. (1999a), "Determinants of Commitment and Opportunism: Integrating and Extending Insights from Transaction Cost analysis and Relational Exchange Theory," Canadian Journal of Administrative Sciences, Vol. 16 No.4, pp. 334-352 and (1999b), "The Contingent Effect of Specific Asset Investments on Joint Action in ManufacturerSupplier Relationships: An Empirical Test of Moderating Role of Reciprocal Asset Investments, Uncertainty, and Trust," Journal of the Academy of Marketing Science, Vol. 27 No.3, pp. 291-305

Klein, S., Frazier G., and Roth V. (1990), “A Transaction Cost Analysis Model of Channel Integration in International Markets," Journal of Marketing Research, Vol. 27(May), pp. 196-208

Kranton, R. (1996), "Reciprocal Exchange: A Self-Sustaining System," The American Economic Review, Vol. 86(Sep), pp. 830851

Kumar, N., Scheer L., and Steenkamp J.,(1995), The Effects of Perceived Interdependence on Dealer Attitudes, Journal of Marketing 
Research, Vol. 32 (August), P. 348-356

Lohtia, R. and Krapfel R. (1994), “The Impact of Transaction-specific Investments on Buyer-Seller Relationships," Journal of Business and Industrial Marketing, Vol. 9 No.1, pp. 6-16

McEvily, B. and Zaheer A. (1999), "Bridging Ties: A Source of Firm Heterogeneity in Competitive Capabilities," Strategic Management Journal, Vol. 20 No.12, pp. 1133-1156

McFarland, R., Bloodgood J., and Payan J., (2008), Supply Chain Contagion, Journal of Marketing, Vol. 72 (March), P. 63-79

Mohr, J., Fisher R., \& Nevin J. (1996), "Collaborative Communication in Interfirm Relationships: Moderating Effects of Integration and Control," Journal of Marketing, Vol. 60(July), pp. 103-115

Murayama, K. and Elliot A. (2012), "The Competition-Performance Relation: A MetaAnalytic Review and Test of Opposing Process Model of Competition and Performance," Psychological Bulletin, Vol. 138 No.6, pp. 1035-1070

Noordhoff, C., Kyriakopoulos K., Moorman C., Pauwels P., and Dellaert B. (2011), "The Bright Side and Dark Side of Embedded Ties in Business-to-Business Innovation," Journal of Marketing, Vol. 75, pp.34-52

Ng, D. (2004), "The social dynamics of divers and closed networks," Human Systems Management, Vol. 23, pp. 111-122

Pfeffer, J. (1972), "Merger as a Response to
Organizational Interdependence," Administrative Science Quarterly, Vol. 17(September), pp. 382-394 and Salancik G. (1978), The External Control of Organizations: A Resource Dependence Perspective, Harper \& Row, New York NY

Portes, A. and Sensenbrenner J. (1993), "Embeddedness and immigration: Notes on the social determinants of economic action," American Journal of Sociology, Vol. 98. pp. 1320-1350

Reagans, R. and Zuckerman E. (2001), "Networks, diversity, and productivity: The social capital of corporate R\&D teams," Organization Science, Vol. 12 No.4, pp. 502-517

Rindfleisch, A. and Heide J. (1997), "Transaction Cost Analysis: Past, Present, and Future Applications," Journal of Marketing, Vol. 61(October), pp. 30-54 and Moorman C. (2001), "The Acquisition and Utilization of Information in New Product Alliances: A Strength-ofTies Perspective," Journal of Marketing, Vol. 65(April), pp. 1-18

Rodan, S. and Galunic C. (2001), "More than Network Structure: How Knowledge Heterogeneity Influences Managerial Performance and Innovativeness," Strategic Management Journal, Vol. 25 No.6, pp. 541-562

Ryu, S., Cho H., and Kim K. (2013), Effects of network embeddedness on the relationship between environmental volatility and interfirm 
contracts, Journal of Business-to-Business

Marketing, Vol. 20 (3) 139-153

Salancik, G. (1995), "Wanted: A good Network

Theory of Organization," Administrative

Science Quarterly, Vol. 40(2), pp. 345-349

Samaha, S., Palmatier R., and Dant R. (2011),

"Poisoning Relationships: Perceived Unfairness

in Channels of Distribution," Journal of

Marketing, Vol. 75 (May), pp. 99-117

Swaminathan, V. and Moorman C. (2009),

"Marketing Alliances, Firm Networks, and

Firm Value Creation," Journal of Marketing;

Vol. 73(September), pp. 52-69

Vázquez, R., Iglesias V., Rodríguez-del-Bosque

I. (2007). "The Efficacy of Alternative Mechanisms in Safeguarding Specific Investments from Opportunism," Journal of Business and Industrial Marketing, Vol. 22 No.7, pp. 498-507

Walker, G., and Weber D. (1984), A Transaction Cost approach to Make-or-Buy Decisions, Administrative Science Quarterly, Vol. 29 (4), pp. 373-391

Wang, D., Gu F., and Dong M. (2013), Observer Effects of Punishment in a Distribution Network, Journal of Marketing Research, Vol. 50(October), pp. 627-643

Wathne, K. and Heide J. (2000), "Opportunism in Interfirm Relationships: Form, Outcomes, and Solutions," Journal of Marketing, Vol. 64(October), pp. 36-51 , Biong H., and (2001), "Choice of Supplier in Embedded Markets:
Relationships and Marketing Program Effects," Journal of Marketing, Vol. 65 (January), pp. 54-66

Williamson, O. (1975), Markets and Hierarchies: Analysis and Antitrust Implications, The Free Press, New York NY:

(1985) The Economic Institutions of Capitalism: Firms, Markets, Relational Contracting, The Free Press, New York NY:

(1996), The Mechanisms of Governance, Oxford University Press, Inc., New York NY

Wuyts, S. (2007), "Extra-role Behavior in Buyer-Supplier Relationships," International Journal of Research in Marketing, Vol. 24 (4), pp. 301-311

Wuyts, S., Stremersch S., Van den Bulte Ch., and Franses H. (2004), "Vertical Marketing Systems for Complex Products: A Triadic Perspective," Journal of Marketing Research, Vol. 41(November), pp. 479-487

Wuyts, S. and Van den Bulte C. (2012), "Network Governance" in Lilien G. and Grewal R. (Ed.), Handbook of Business-to-Business Marketing, Edward Elgar Pub., London UK

Yu, C., Liao T., and Lin Z. (2006), "Formal Governance Mechanisms, Relational Governance Mechanisms, and Transaction-specific Investments in Supplier-Manufacturer Relationships," Industrial Marketing Management, Vol.35 No.2, pp. 128-139 